\title{
Bullying Practice and the Understanding of Gender Equality in Senior High School Students in Mataram City
}

\author{
Hamidsyukrie ZM* \\ Sociology Education Study Program \\ Faculty of Teacher Training and Education (FKIP) \\ Universitas Mataram \\ Mataram, Indonesia \\ hamidsyukriezm@unram.ac.id \\ Muhammad Ilyas \\ Sociology Education Study Program \\ Faculty of Teacher Training and Education (FKIP) \\ Universitas Mataram \\ Mataram, Indonesia
}

\author{
Ni Made Novi Suryanti \\ Sociology Education Study Program \\ Faculty of Teacher Training and Education (FKIP) \\ Universitas Mataram \\ Mataram, Indonesia \\ Nurlaili Handayan \\ Sociology Education Study Program \\ Faculty of Teacher Training and Education (FKIP) \\ Universitas Mataram \\ Mataram, Indonesia
}

\begin{abstract}
This study aimed to reveal the reasons and forms of bullying committed by male students to female students as well as understanding gender equality in senior high school students in the city of Mataram. This study employed a qualitative approach with a case study method. Data collection was done through interview, Focus Group Discussion (FGD), observation, and documentation. Data were analyzed qualitatively by triangulation (techniques and sources), reduction, display, and verification/conclusion. The results show that there was some bullying in senior high schools in Mataram. Many male students did bullying towards female students. They did bullying to female students in the form of physical, verbal, and nonverbal by using body movements, writing or pictures. They considered those bullying actions as joke and to show their power and strength to other students. The students have lack of understanding on gender equality. Male students dominated intra and extracurricular activities more than female students. Bullying, in the short term, can lead to the feelings of insecurity, isolation, low of self-esteem, depression, and suffering from stress. Due to the fact of many cases of bullying in schools, it is suggested, as the solution, to develop an antibullying policy and to apply gender equality education in order to stop or minimize the practice of bullying toward the female students in formal education environment.
\end{abstract}

Keywords - bullying, gender, equity

\section{INTRODUCTION}

The purpose of education is to encourage individuals who are able to humanize humans. In order to achieve this educational goal, it is a need for learning conditions such as conducive, safe, comfortable, and being far from various actions that might endanger students. Schools must provide comfort situation and knowledge for students, and this is as has been mandated in Article 54 of Law Number 23 Year 2002 concerning child protection, in which it is stated that "children in and within the school environment must be protected from any acts of violence committed by teacher, school manager or friends in their school or from other educational institutions ".

Unfortunately, we often get information from several media in which cases of violence in the world of education significantly increase in number. In general, an act of violence can be interpreted as an act that harms others, both physically and psychologically. Acts of violence that occur in the world of education are better known as bullying. Schools that should be a place to gain knowledge, develop potential, and help shaping positive personal character for students has turned out to be a place for bullying. This case seems like an iceberg phenomenon that only looks a little on the surface, but actually it looks bigger if we examine it deeper.

According to KPAI data, the number of educational cases as of 30 May 2018 is 161 cases, in which 23 (14.3\%) cases are brawl victims, 31 cases $(19.3 \%)$ are brawlers, 36 cases $(22.4 \%)$ are violence and bullying victims, 41 cases $(25.5 \%)$ are violence and bullying children, and 30 cases $(18.7 \%)$ are victims of the policy such as extortion, being expelled from school, being not allowed to take the exam, and drop out of school. These data show that from several types of violence that occurred in the field of education (school), bullying behaviours occupy the top rank. Bullying can be done by the teacher to students, students to other students, male students to female students, a group of students to the other groups. Bullying has a great chance to be imitated because this negative behaviour is mostly practiced by students.

Students tend to bully after they themselves have been hurt by a stronger person, for example by parents, older siblings, or more dominant peers. If a large number of students do bullying, or bullying is done by students who have influence in class, then other students will most likely participate in bullying too, or at least consider bullying to be normal behaviour. The phenomenon of bullying has become a part of school dynamics. Generally, bullying is 
more familiar for the people with terms such as ostracized, intimidation and the like. According to [1], the term bullying itself has a broader meaning, encompassing various forms of the use of power to hurt others, so that victims feel depressed, traumatized, and helpless. Bullying takes many forms, such as direct physical bullying, verbal ridicule and threat, insults, relational or social bullying, and cyberbullying. Although physical bullying and cyberbullying often attract great social attention, social and verbal bullying are commonly experienced by students [2].

A study conducted by Amini [3] shows that bullying behavior that occurred at the senior high school level was $67.9 \%$, whereas at the junior level was $66.1 \%$. The results of this study found the high frequency accidents of bullying were in the form of psychological violence, exclusion, and verbal violence such as mocking and hitting. Bullying committed by male students to male students is more visible and tends to be in physical behavior; whereas bullying done by male students to female students is more likely to be psychological/verbal. Male and female students committed bullying to other students directly and indirectly, and most of male students are more likely to use physical bullying. The study conducted by Gadin [4] explained that both boys and girls have the same potential to become victims of sexual harassment, but in terms of experience and frequent events, girls are at high risk of experiencing cross-gender sexual abuse situations. Moreover, it was pointed out that gender is an important dimension in relation to the social structure that is influenced by power relations, division of labor, allocation of resources, symbols, and social construction of masculinity and feminists. In particular, gender-based violence is more commonly experienced by girls [4].

Based on the problems stated above, the researchers aimed at carrying out a study about the practice of bullying and the understanding of the concept of gender equality in high schools in the city of Mataram. In addition, the results of this study hopefully will be a reference or a basis for an educational policy dealing with the gender education in secondary schools to suppress the occurrence of bullying.

\section{RESEARCH METHOD}

This research employed qualitative approach with a case study method. The aim was to reveal the practice of bullying and the concept of gender equality in high school students in the city of Mataram. This research was conducted to find and show the real conditions that occur through direct observation and interview with triangulation technique. This research was basically to find out the actualization, social reality, and perception of a person through recognition that may not be revealed or measured by any other instruments in common, or even by a list of questions that have been prepared in advance. The data were collected by using observation, interviews, focus group discussions, and documentation.

To check validity of the data, the researchers conducted a triangulation activity that was re- checking from various sources, different ways and time. Triangulation was done by comparing information from one person to information from others. Then, researchers need to crosscheck the information and thus the data gotten were in criteria of valid and not subjective. In addition, this research used technical triangulation and source triangulation in testing the validity of the data. Data were analyzed qualitatively through data reduction, data display, and verification/conclusion.

\section{RESULTS AND DISCUSSION}

\section{A. Reasons Why Students Do Bullying}

The results indicated that students did bullying because they considered it as jokes, wanted to be famous and to be dominating among other students. Bullying will not occur if there is no trigger. The following are some of reasons for bullying behavior as a result of interviews with teachers and students. One student stated that he liked to disturb his friends, but his motives are merely for a joke. This finding was in line with the previous research [5] which stated that bullying behavior that was commonly found among high school students in Asia-Pacific was merely for a joke. Other students admitted that they liked to annoy others because they want to be famous. This usually happened from senior students, who considered themselves to have power to control their juniors. According to an informant, students who like to do bullying are senior students. Moreover, another informant stated that this is a common motive for a student to bully others. In many cases, behavior with this motive is considered not harmful to the victim.

Meanwhile, Katyana Wardana [6] argued that students who tend to do bullying generally have the following characteristics: (1) students who are jealous due to failures in academic or non-academic matters; (2) students who experience family problems; (3) students who are too spoiled at home; (4) students who psychologically feel unable to compete with victims of bullying; (5) students who see other students weaker than them; (6) students who do not have views for the future or they don't care of the consequence of their actions; and (7) students who do not get the attention from their parents or teachers.

Other findings show that the victims of bullying are those who appear to have physical and psychological deficiencies such as students who are fat, thin, tall, short, have disabilities, and introvert. This was in line with the finding of study by Katyana Wardana [6] in which the students who tend to be bullied usually have the characteristics, such as: (1) students who tend to be difficult to socialize; (2) students who are physically different from other students; (3) students who tend to be different from other students (coming from well-off or economic disadvantaged families); (4) obedient students because of anxiety, lack of confidence, fear of being hated and want of pleasing other students; (5) students with annoying behavior; (6) students are shy, introvert or do not want to attract the attention of other students; and (7) students who have physical disabilities or mental retardation. Those seven characteristics are the general characteristics of students who are usually as the target of bullying. In short, students who are targeted by bullying are those who look different from other students and this difference can be caused by the shortcomings. 


\section{B. Students' Understanding of Gender Equality}

In this part, bullying behavior is focused on gender aspects, equality of roles between male and female students and the students' understanding of the gender equality. The results indicated that students did not understand the concept of gender. The involvement of male students in bullying was generally more frequent than female students in which $80.0 \%$ was for male and $20.0 \%$ was for female students. In other words, male students tend to do bullying more than female students.

Regarding the aspect of being a victim of bullying, female students are more often considered as victims of bullying. Socio-cultural construction influences personality, traits, and emotions directly and indirectly towards women. In a patriarchal culture, girls are demanded to be more feminine, gentle, obedient, patient, not arguing, and so on. Thus, this might shape the personality of girls to be shy, more aloof, and accept what they are. On the other hand, boys are demanded to be more active and not whiny and this can shape their personality to be brave and confident [7]. In addition to socio-cultural factor, there is an androgen hormone that forms boys to behave in a masculine manner that carries the character of a man such as aggressive, brave, and confident. On the other hand, girls have the hormone of estrogen which can form feminine behavior that carries the nature of a woman such as shy, introvert, fear, whiny, coward and impulsive [8]. These findings were in line with the literature dealing with phenomenon of bullying which state that male students tend to be involved in bullying as perpetrators more than female students do [9]-[11]. Interestingly, other findings found that bullying behavior in the form of taunts and disguises, female students dominate as perpetrators rather than male students. This finding strengthens the stereotype of women as a gentle figure and avoiding acts of physical violence.

\section{Forms of Bullying Performed by Male Students Against Female Students}

The results revealed that there were various forms of bullying committed by male students toward female students. The form was physical bullying such as pushing, pinching, pulling, scratching, verbal bullying such as dub, cussing, insulting, making fun of, and non-verbal bullying such as silence, glaring, threatening with bodily movements or through writing, and shouting. Mellor [12] explained that there are several types of bullying, namely: (1) physical bullying that is a type of bullying which involves physical contact between the perpetrator and the victim; (2) verbal bullying which involves verbal language intended to hurt someone or that which involve acts of aggression committed by the perpetrators to their victims by issuing words and this is in line with the finding of this study; (3) social bullying is a type of bullying that aims to reject and sever the victim's social relations with others, including weakening the victim's self-esteem through neglection, exclusion or avoidance; and (4) electronic bullying is a form of bullying through electronic media.

\section{CONCLUSION}

Bullying behavior is a common phenomenon that occurs among school students. The findings of this study show that there are several reasons underlying the bullying behaviors among male students towards female students. First, this kind of behavior is carried out only for a joke and it does not intend to hurt the victims. Second, students do bullying because they are senior and have power over the victims. Regarding the aspect of gender equality, male students are more dominant in school activities than female students. In addition, students' understanding of gender equality is inadequate, there is even a recognition that they do not understand about the knowledge of gender equality. The findings of the study also reveal that bullying behavior was mostly done by male students towards female students. This is due to male students were more dominating and have more power than female students. Third, the forms of bullying behavior carried out are physical, verbal, and nonverbal with body movements, through writing or pictures. It can be seen from the phenomenon number of bullying behavior that significantly increase and continuously happen in school environment, especially bullying committed by male students toward female students. Therefore, the antibullying policy for female students needs to be implemented through gender equality education as a way to overcome bullying behavior in schools.

\section{REFERENCES}

[1] D. Damantari, Perilaku Bullying pada Remaja di Sekolah Ditinjau dari Jenis Kelamin. Surakarta: Universitas Muhammadiyah, 2011.

[2] S. Hymel and S. M. Searer, "Four Decades of Research on School Bullying," Am. Psychol. Assoc., vol. 70, no. 4, pp. 293299, 2015.

[3] Amini, Bullying mengatasi kekerasan di sekolah dan lingkungan sekitar siswa. Jakarta: PT. Grasindo, 2008.

[4] K. G. Gådin, "Sexual harassment of girls in elementary school: A concealed phenomenon within a heterosexual romantic discourse," J. Interpers. Violence, vol. 27, no. 9, pp. 17621779, 2012.

[5] S.-L. Lai, R. Ye, and K.-P. Chang, "Bullying in middle schools: An Asian-Pacific regional study," Asia Pacific Educ. Rev., vol. 9, no. 4, pp. 503-515, 2008.

[6] A. Fitriyah, "Prevensi Bullying Siswa Dyslexia dalam Praktiknya di Lembaga Pendidikan Islam," Edukasia J. Penelit. Pendidik. Islam, vol. 12, no. 1, pp. 165-188, 2017.

[7] J. W. Santrock, Perkembangan Anak. Jilid 1 Edisi kesebelas. Jakarta: Erlangga, 2007.

[8] H. S. Friedman and M. W. Schustack, Kepribadian: Teori Klasik dan Riset Modern. Jakarta: Erlangga, 2006.

[9] D. Olweus, Bullying at school:What we know and what we can do. Cambridge: Blackwell, 1993.

[10] K. Rigby, Children and bullying.how parents and educators can reduce bullying at school. California: Blackwell, 2008.

[11] S. Wimmer, "Views on gender differences in bullying in relation to language and gender role socialisation," Griffith Work. Pap. Pragmat. Intercult. Commun., vol. 2, pp. 18-26, 2009.

[12] A. Mellor, "Sebuah Pendekatan Sistematik terhadap Pengembangan Kebijakan Anti-Bullying yang Efektif di Lingkungan Sekolah," 2019. [Online]. Available: www.ditplb.or.id. 